Key Words:

Film thickness

MCU, Decontamination

Solvent Extraction

Retention: Permanent

\title{
DETERMINATION OF LIQUID FILM THICKNESS FOLLOWING DRAINING OF CONTACTORS, VESSELS, AND PIPES IN THE MCU PROCESS
}

Michael R. Poirier

Fernando F. Fondeur

Samuel D. Fink

June 6, 2006 
This document was prepared in conjunction with work accomplished under Contract No. DEAC09-96SR18500 with the U. S. Department of Energy.

\section{DISCLAIMER}

This report was prepared as an account of work sponsored by an agency of the United States Government. Neither the United States Government nor any agency thereof, nor any of their employees, nor any of their contractors, subcontractors or their employees, makes any warranty, express or implied, or assumes any legal liability or responsibility for the accuracy, completeness, or any third party's use or the results of such use of any information, apparatus, product, or process disclosed, or represents that its use would not infringe privately owned rights. Reference herein to any specific commercial product, process, or service by trade name, trademark, manufacturer, or otherwise, does not necessarily constitute or imply its endorsement, recommendation, or favoring by the United States Government or any agency thereof or its contractors or subcontractors. The views and opinions of authors expressed herein do not necessarily state or reflect those of the United States Government or any agency thereof. 


\title{
DETERMINATION OF LIQUID FILM THICKNESS FOLLOWING DRAINING OF CONTACTORS, VESSELS, AND PIPES IN THE MCU PROCESS
}

\author{
By Michael R. Poirier, Fernando F. Fondeur, and Samuel D. Fink
}

\begin{abstract}
The Department of Energy (DOE) identified the caustic side solvent extraction (CSSX) process as the preferred technology to remove cesium from radioactive waste solutions at the Savannah River Site (SRS). As a result, Washington Savannah River Company (WSRC) began designing and building a Modular CSSX Unit (MCU) in the SRS tank farm to process liquid waste for an interim period until the Salt Waste Processing Facility (SWPF) begins operations. Both the solvent and the strip effluent streams could contain high concentrations of cesium which must be removed from the contactors, process tanks, and piping prior to performing contactor maintenance. When these vessels are drained, thin films or drops will remain on the equipment walls. Following draining, the vessels will be flushed with water and drained to remove the flush water. The draining reduces the cesium concentration in the vessels by reducing the volume of cesium-containing material. The flushing, and subsequent draining, reduces the cesium in the vessels by diluting the cesium that remains in the film or drops on the vessel walls.
\end{abstract}

MCU personnel requested that Savannah River National Laboratory (SRNL) researchers conduct a literature search to identify models to calculate the thickness of the liquid films remaining in the contactors, process tanks, and piping following draining of salt solution, solvent, and strip solution.

The conclusions from this work follow.

- The predicted film thickness of the strip effluent is $0.010 \mathrm{~mm}$ on vertical walls, $0.57 \mathrm{~mm}$ on horizontal walls and $0.081 \mathrm{~mm}$ in horizontal pipes.

- The predicted film thickness of the salt solution is $0.015 \mathrm{~mm}$ on vertical walls, $0.74 \mathrm{~mm}$ on horizontal walls, and $0.106 \mathrm{~mm}$ in horizontal pipes.

- The predicted film thickness of the solvent is $0.022 \mathrm{~mm}$ on vertical walls, $0.91 \mathrm{~mm}$ on horizontal walls, and $0.13 \mathrm{~mm}$ in horizontal pipes.

- The calculated film volume following draining is

○ Salt solution receipt tank - 1.6 gallons

- Salt solution feed tank - 1.6 gallons

○ Decontaminated salt solution hold tank -1.6 gallons

○ Contactor drain tank -0.40 gallons

○ Strip effluent hold tank - 0.33 gallons

- Decontaminated salt solution decanter -0.37 gallons

- Strip effluent decanter - 0.14 gallons

○ Solvent hold tank -0.30 gallon

○ Corrugated piping between contactors $-16-21 \mathrm{~mL}$

- After the initial vessel draining, flushing the vessels with 100 gallons of water using a spray nozzle that produces complete vessel coverage and draining the flush water reduces the source term by the follow amounts. 
- Salt solution receipt tank $-63 X$

- Salt solution feed tank - 63X

- Decontaminated salt solution hold tank - 63X

- Contactor drain tank - 250X

- Strip effluent hold tank - 300X

- Decontaminated salt solution decanter $-270 X$

- Strip effluent decanter $-710 \mathrm{X}$

○ Solvent hold tank - 330X

Understand that these estimates of film thickness are based on laboratory testing and fluid mechanics theory. The calculations assume drainage occurs by film flow. Much of the data used to develop the models came from tests with very "clean" fluids. Impurities in the fluids and contaminants on the vessels walls could increase liquid holdup. The application of film thickness models and source term reduction calculations should be considered along with operational conditions and H-Tank Farm/Liquid Waste operating experience. These calculations exclude the PVV/HVAC duct work and piping, as well as other areas that area outside the scope of this report.

\section{INTRODUCTION}

The Department of Energy identified the CSSX process as the preferred technology to remove cesium from radioactive waste solutions at the SRS. ${ }^{1,2}$ As a result, WSRC began designing and building a MCU in the SRS tank farm to process liquid waste for an interim period until the SWPF begins operations. Both the MCU and SWPF use the CSSX technology although the facilities differ in size and processing rate.

The solvent contacts SRS liquid waste in centrifugal contactors. During the contact, cesium is transferred from the aqueous phase (i.e., salt solution) to the solvent and the aqueous and organic phases are separated. The solvent is stripped of cesium by dilute nitric acid in other contactors. Following separation of the strip solution from the solvent, the strip effluent is transported to the DWPF. The decontaminated aqueous salt solution is transported for ultimate disposal through the Saltstone Production Facility.

The salt solution, solvent, and strip effluent streams may retain high concentrations of cesium that must be removed from the contactors, process tanks, and piping prior to performing contactor maintenance. When these vessels are drained, thin films or drops will remain on the equipment walls. Following draining, the vessels will be flushed with water and drained to remove the flush water. The draining reduces the cesium concentration in the vessels by reducing the volume of cesium-containing material. The flushing, and subsequent draining, reduces the cesium in the vessels by diluting the cesium that remains in the film or drops on the vessel walls.

MCU personnel requested that SRNL personnel conduct a literature search to identify models for calculating the thickness of the liquid films remaining in the contactors, process tanks, and piping following draining of salt solution, solvent, and strip solution. Similarly, MCU requested that SRNL estimate the flushing efficiency and effective decrease in concentration of the soluble cesium. 


\section{LITERATURE SEARCH}

We identified published literature addressing two situations with similar physics: drainage of liquid through an opening in the bottom of a tank and the slow withdrawal of a solid object from a quiescent liquid. ${ }^{3}$ In both cases, the liquid will initially drain rapidly. After most of the liquid drains, a thin film remains that drains much slower. Eventually, surface tension and viscous forces sufficiently exceed the gravitational forces and the liquid ceases to drain. The film may break and form droplets. The goal of this task is to identify methods to calculate the liquid film thickness after gravity drainage stops.

Levich describes an approach for calculating the thickness of a film on the surface of a solid withdrawn from a quiescent liquid. ${ }^{4}$ He assumes that the plate was withdrawn from the liquid at a low velocity and that the plate is significantly above the quiescent liquid. The liquid film properties are a function of viscous, gravity, and capillary forces. The thickness is a function of withdrawal rate, liquid viscosity, density, gravitational acceleration, and surface tension. Equation 1 describes the thickness (h) of the liquid film on a vertical surface

$$
\mathrm{h}=0.93 \frac{(\mu \mathrm{v})^{2 / 3}}{\sigma^{1 / 6}(\rho \mathrm{g})^{1 / 2}}
$$

where $\mu$ is the liquid viscosity, $v$ is the liquid velocity, $\sigma$ is the surface tension, $\rho$ is the liquid density, and $\mathrm{g}$ is gravitational acceleration.

Groenveld ${ }^{5}$ describes models for calculating the thickness of the liquid film that clings to the inside of a vessel following draining. For low speed draining of the liquid $(\mu v / \sigma<0.02)$, the film thickness is described by equation 2 .

$$
\mathrm{h}=0.94\left(\frac{\mu \mathrm{v}}{\sigma}\right)^{1 / 6} \sqrt{\frac{\mu \mathrm{v}}{\rho \mathrm{g}}}
$$

Spiers et al. ${ }^{6}$ developed models describing the liquid film formed on solid surfaces vertically withdrawn from a quiescent liquid. They found that four forces influence the film formed on the solid surface: viscous, gravitational, surface tension, and inertia forces. At low withdrawal speeds, the inertia forces can be neglected. They identified three regions in the film. In region 1, far from the liquid surface, the film thickness is constant and only viscous and gravity forces are involved. In region 2, the film thickness varies with height above the liquid, and viscous, gravity, and surface tension forces are significant. In region 3, close to the liquid surface, only surface tension forces are significant. Regions 1 and 2 are applicable to draining MCU vessels.

Equation 3 describes the film thickness in region 1.

$$
\mathrm{h}=0.944 \frac{(\mu \mathrm{v})^{2 / 3}}{\sigma^{1 / 6}(\rho \mathrm{g})^{1 / 2}}
$$


Equations $4-6$ describe the film thickness in region 2.

$$
\begin{aligned}
& \frac{\mathrm{T}}{\left(1-\mathrm{T}^{2}\right)^{2 / 3}}=0.944 \mathrm{Ca}^{1 / 6} \\
& \mathrm{~T}=\mathrm{h}\left(\frac{\rho \mathrm{g}}{\mu \mathrm{v}}\right)^{1 / 2} \\
& \mathrm{Ca}=\frac{\mu \mathrm{v}}{\sigma}
\end{aligned}
$$

The authors also present experimental data describing the film thickness of glycerol-water, sugar syrup-water, liquid paraffin, and lubricating oil solutions of varying viscosity. The liquid viscosity in the testing was $18-2000 \mathrm{cp}$, which is much higher than expected in the MCU vessels. At low capillary numbers $(\mathrm{Ca})$, the film thickness is bounded by $\mathrm{T}=0.3$.

Takahama et al. ${ }^{7}$ measured the flow characteristics of liquid films (water) falling along the wall of a vertical brass cylinder and developed a model to describe the film thickness under laminar conditions. Equation 7 describes their model of the film thickness

$$
\mathrm{h}=\left(\frac{3 \mu^{2} \operatorname{Re}}{\rho^{2} g}\right)^{1 / 3}
$$

where Re is the Reynolds number.

Moran et al. ${ }^{8}$ measured the characteristics of falling films on inclined plates and developed a model to describe the film thickness as a function of viscosity, Reynolds number and slope. The plate was copper with polycarbonate side walls. The liquid was silicone fluid 200 with $0.2 \mathrm{~cm}^{2} / \mathrm{s}$ kinematic viscosity, $0.96 \mathrm{~g} / \mathrm{cm}^{3}$ density, and 20.6 dyne $/ \mathrm{cm}$ surface tension. The Reynolds number was $11-220$. Equation 8 describes their model

$$
h=0.97\left(\frac{\mu^{2}}{\rho^{2} g \cos (\theta)}\right)^{1 / 3} \operatorname{Re}^{1 / 3}
$$

where $\theta$ is the slope of the plate (with $0^{\circ}$ being vertical and $90^{\circ}$ being horizontal).

Yeong et al. measured the liquid film thickness in microstructured falling film reactors with acetone, ethanol, and isopropanol. ${ }^{9}$ Fluid viscosity was $0.34-2.3 \mathrm{cp}$, which is close to the viscosity of the liquids in the MCU process $(1-4 \mathrm{cp})$. Surface tension was $14-23$ dynes $/ \mathrm{cm}$, which is lower than the surface tension of the liquids in the MCU process $(24-59$ dynes $/ \mathrm{cm})$. Density was $0.79 \mathrm{~g} / \mathrm{cm}^{3}$, which is lower than the density of the liquids in the MCU process $(0.87$ $-1.25 \mathrm{~g} / \mathrm{cm}^{3}$ ). The reactors were fabricated from stainless steel and gamma alumina-coated stainless steel. The Reynolds number in their testing varied between 0.04 and 0.86 . With the 
stainless steel reactors, the liquid film thickness was bounded by the predictions from the correlations of Nusselt and Kapitza, which are shown in equations 9 and 10.

$$
\begin{aligned}
& h=\left(\frac{3 \mu^{2}}{\rho^{2} g \cos (\theta)}\right)^{1 / 3} \operatorname{Re}^{1 / 3} \\
& h=\left(\frac{2.4 \mu^{2}}{\rho^{2} g \cos (\theta)}\right)^{1 / 3} \operatorname{Re}^{1 / 3}
\end{aligned}
$$

As the liquid drains from the tanks, the film thickness will decrease. Eventually, the film will become unstable and rivulets, or "waves", will form. As the thickness decreases further, "dry spots" will form on the solid surface. ${ }^{10}$ Mikielewicz and Moszynski measured the critical thickness, below which rivulets form for a water stainless steel system. The critical thickness is described by equation 11 .

$$
\mathrm{h}^{+}=\left(\frac{\rho^{3} \mathrm{~g}^{2}}{15 \mu^{2} \sigma}\right)^{1 / 5} \mathrm{~h}
$$

After reaching this critical thickness, the film will continue to drain, but the film shape and drainage rate will change. For stainless steel-water, they measured the dimensionless critical thickness $\left(\mathrm{h}^{+}\right)$to be 0.90 .

Eventually, the "wavy film" could give way to drops. Depending on the drop diameter, surface tension, contact angle, and viscosity, drops below a certain diameter will not drain. O'Neill and Westwater measured the dropwise condensation of steam on electroplated silver surfaces. ${ }^{11}$ Photographs in their paper suggest the drops could be as large as $3.3 \mathrm{~mm}$. These large drops cover a small fraction of the surface. Most of the surface is covered by small drops $(<0.1 \mathrm{~mm})$ or bare. Assuming the drop volume is a semi-sphere with $3.3 \mathrm{~mm}$ diameter, calculating the volume of the large droplets, and dividing by the surface area of the disk, one calculates the average film thickness to be $0.1 \mathrm{~mm}$.

Following completion of the 96 hour durability test and the upset transition tests, Wright Industries conducted clean in place tests on all of the contactors, disassembled the contactors, and photographed the interior. Figure 1 shows the interior of Strip contactors 1, 2, 3, and 4.

The contactor walls show the presence of small droplets rather than a liquid film. The authors measured the size of the largest droplets observed from the photographs and used the diameter of the contactor (5 inches) to estimate the size of these droplets $(\sim 1 \mathrm{~mm})$. Many of the droplets are much less than $1 \mathrm{~mm}$. 


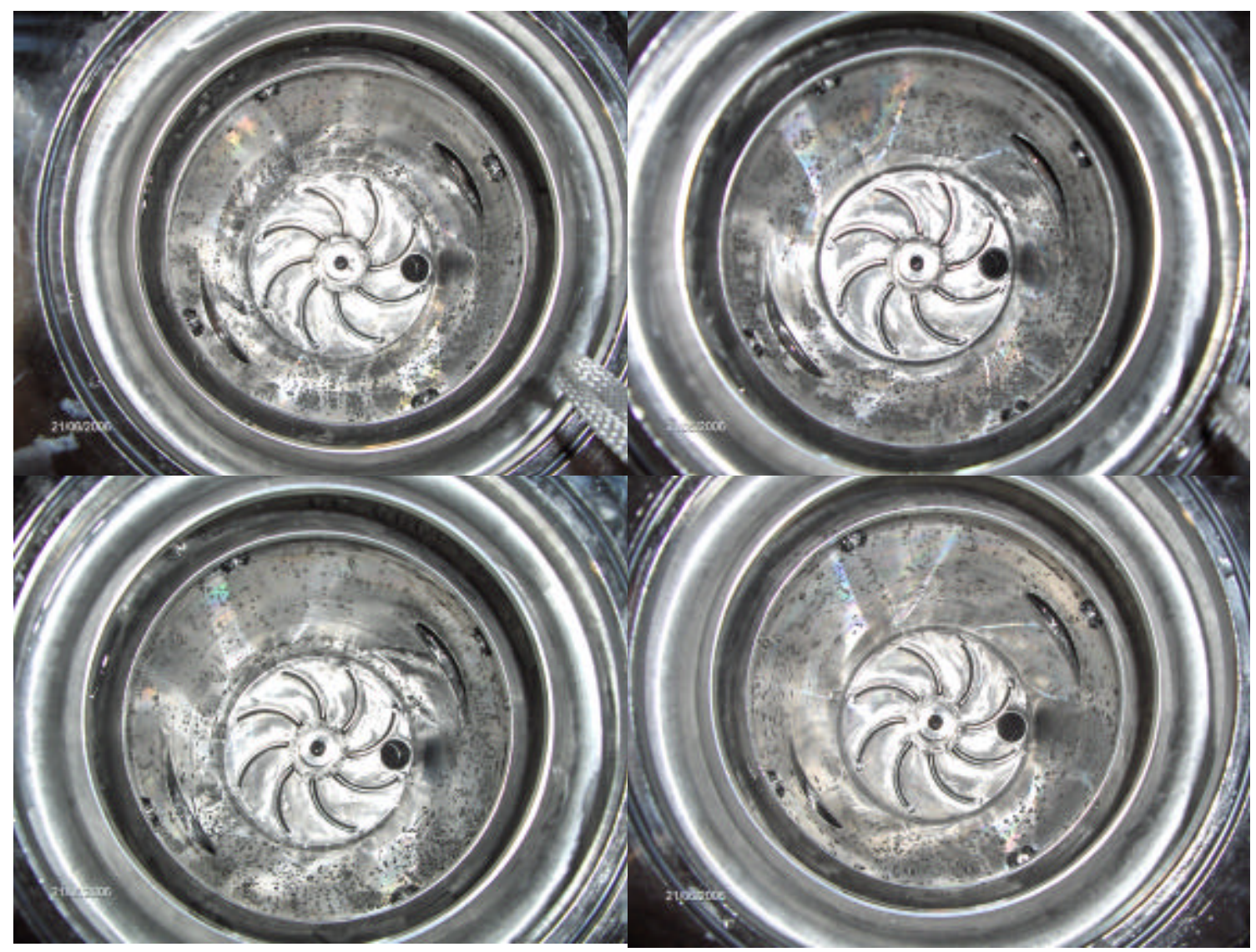

Figure 1. Interior of Strip Contactors 1, 2, 3, and 4 following Clean In Place Test

One of the authors examined the photographs with ImageJ 1.36b software from the National Institute of Health. The program looks for edges of objects based on contrast differences in the image. It identifies edges and discretizes the picture into a binary image. The software calculates the area of the dark colored features and compares this area to the entire image or selected area. The authors employed this software to calculate the fraction of the surface covered by droplets, which averaged $7.3 \pm 0.9 \%$ for the four contactors. Since the camera was positioned above the contactors rather than perpendicular to the wall, the projected area of a drop will be larger than its cross-section. The actual fraction of the surface covered by drops is less than the $7.3 \%$ calculated by the software.

If the droplets are semi-spheres with diameter of $1 \mathrm{~mm}$, the droplet volume is $0.26 \mathrm{~mm}^{3}$. The surface area of the contactor walls is $\pi \mathrm{DH}$, where $\mathrm{D}$ is the contactor diameter, and $\mathrm{H}$ is the height. Taking a $1 \mathrm{~mm}$ strip around the circumference of the contactor, the surface area of the strip is $399 \mathrm{~mm}^{2}$. If the large droplets occupy $7.3 \%$ of the surface area, they cover $29.1 \mathrm{~mm}^{2}$ of the strip. Since the cross-sectional area of these droplets is $\pi \mathrm{D}^{2} / 4$, the number of droplets in the cross-section can be calculated with equation 12 .

$$
\mathrm{N}=29.1 \mathrm{~mm}^{2} / \pi(.5)^{2} \mathrm{~mm}^{2}=37
$$

The volume of these droplets is $9.64 \mathrm{~mm}^{3}\left(37 * 0.26 \mathrm{~mm}^{3}\right)$. We calculate the equivalent film thickness by dividing the droplet volume by the surface area of the $1 \mathrm{~mm}$ strip. The calculated 
equivalent film thickness is $0.024 \mathrm{~mm}\left(9.64 \mathrm{~mm}^{3} / 399 \mathrm{~mm}^{2}\right)$. This calculation assumes all of the droplets are $1 \mathrm{~mm}$ in size. Since many droplets are much less than $1 \mathrm{~mm}$ in size, this calculation is conservative and the actual equivalent film thickness will be less.

\section{RESULTS}

We used the models described above to calculate the film thickness on vertical walls of vessels, on vessel bottoms, and in pipelines. We considered three liquids: salt solution, strip effluent, and solvent. Table 1 shows the properties of these liquids. ${ }^{12}$ We arbitrarily assumed a liquid velocity (i.e., drainage rate or withdrawal rate) of $1 \mathrm{~cm} / \mathrm{s}$. Tallmadge selected this value to represent a low velocity in his studies. ${ }^{13}$ A lower velocity would produce a thinner film according to equations $1-11$. This rate will produce a thickness that bounds the film properties when the liquid has ceased draining.

Table 1. Liquid Properties ${ }^{12}$

\begin{tabular}{|c|c|c|c|}
\hline Property & $\underline{\text { Strip Effluent }}$ & $\underline{\text { Salt Solution }}$ & $\underline{\text { Solvent }}$ \\
\hline Viscosity (cp) & 1 & 3 & $\overline{4}$ \\
\hline Surface tension (dyne/cm) & 36 & 59 & 24 \\
\hline Density $\left(\mathrm{g} / \mathrm{cm}^{3}\right)$ & 1.0 & 1.25 & 0.87 \\
\hline Kinematic viscosity $\left(\mathrm{cm}^{2} / \mathrm{s}\right)$ & 0.01 & 0.024 & 0.046 \\
\hline $\operatorname{Re}$ & 1 & 0.4 & 0.2 \\
\hline Velocity $(\mathrm{cm} / \mathrm{s})$ & 1 & 1 & 1 \\
\hline $\mathrm{Ca}$ & 0.00028 & 0.00051 & 0.0017 \\
\hline Critical thickness (cm) & 0.032 & 0.048 & 0.056 \\
\hline
\end{tabular}

Table 2 shows the film thickness on vertical walls calculated with the models described earlier. The film thickness predicted by equation 7 is much larger than the predictions from the other equations for each of the liquids. Reviewing the work conducted to develop that model, one sees that the testing occurred at much higher Reynolds numbers than applicable to this case (i.e., $\operatorname{Re}>$ 100). Therefore, we recommend not using that model to calculate the film thickness.

Table 2. Liquid Film Thickness on Vertical Walls

\begin{tabular}{|l|l|l|l|}
\hline Model & $\begin{array}{l}\text { Strip Effluent Film } \\
\text { Thickness }(\mathrm{mm})\end{array}$ & $\begin{array}{l}\text { Salt Solution Film } \\
\text { Thickness }(\mathrm{mm})\end{array}$ & $\begin{array}{l}\text { Solvent Film } \\
\text { Thickness (mm) }\end{array}$ \\
\hline Equation 1 & 0.0076 & 0.013 & 0.022 \\
\hline Equation 2 & 0.0077 & 0.013 & 0.022 \\
\hline Equation 3 & 0.0077 & 0.013 & 0.022 \\
\hline Equation 4 & 0.0077 & 0.013 & 0.022 \\
\hline Spiers et al. data & 0.010 & 0.015 & 0.021 \\
\hline Equation 7 & 0.068 & 0.089 & 0.11 \\
\hline $\begin{array}{l}\text { Average of Equations } \\
\text { - 4 and Spiers et al. }\end{array}$ & 0.00814 & 0.0134 & 0.0218 \\
\hline Standard Deviation & 0.00104 & 0.0009 & 0.0004 \\
\hline Recommendation & 0.010 & 0.015 & 0.022 \\
\hline
\end{tabular}


Our rough estimate of the average thickness of the film from the drops following the clean in place test with the strip decanters $(0.0024 \mathrm{~cm})$ is the same order of magnitude as the strip effluent film thickness calculated in Table $2(0.00076-0.0010 \mathrm{~cm})$. The difference could be from the droplets covering less than $7.3 \%$ of the surface following the cleaning in place tests or from uncertainty in film thickness correlations. The agreement provides confidence that that film thickness equations provide a reasonable estimate of the residual liquid remaining in $\mathrm{MCU}$ vessels following draining. For conservatism, we recommend that MCU personnel use the maximum of the film thicknesses determined from equation 1, equation 2 , equation 3 , equation 4, and the Spiers et al. data.

Table 3 shows the calculated film thickness on the bottom of process vessels. We assumed an angle of $89.9^{\circ}$ for the bottom slope of the tank. In addition, since other researchers investigating liquid films next to a solid surface ${ }^{14}$ have assumed a Reynolds number $(\operatorname{Re}=\rho \mathrm{vh} / \mu)<<1$ for this application, we assumed a Reynolds number of 1 for the strip solution and used the ratio of kinematic viscosity to calculate the Reynolds number for the salt solution $(\operatorname{Re}=0.4)$ and solvent $(\operatorname{Re}=0.2)$. Since the velocity of the film following draining is 0 , this assumption is conservative. Since equation 9 predicts the thickest film, we recommend using it to predict film thickness and will use it in subsequent calculations. For vessel bottoms with greater slope, the film thickness will decrease.

Table 3. Liquid Film Thickness on Vessel Bottom

\begin{tabular}{|l|l|l|l|}
\hline & $\begin{array}{l}\text { Strip Effluent Film } \\
\text { Thickness }(\mathrm{mm})\end{array}$ & $\begin{array}{l}\text { Salt Solution Film } \\
\text { Thickness (mm) }\end{array}$ & $\begin{array}{l}\text { Solvent Film } \\
\text { Thickness (mm) }\end{array}$ \\
\hline Equation 8 & 0.38 & 0.50 & 0.61 \\
\hline Equation 9 & 0.57 & 0.74 & 0.91 \\
\hline Equation 10 & 0.53 & 0.69 & 0.84 \\
\hline Average & 0.49 & 0.64 & 0.79 \\
\hline Standard Deviation & 0.10 & 0.13 & 0.16 \\
\hline Recommendation & 0.57 & 0.74 & 0.91 \\
\hline
\end{tabular}

To calculate the film thickness in the pipes, we assumed horizontal pipes and calculated the thickness over the bottom half of the pipe by numerically integrating equation 9 ove $r$ the bottom half of the pipe. If the pipe is sloped, the film thickness will be less. We then assumed the thickness over the top half of the pipe to be the same as the thickness at the side of the pipe (using equation 9). This assumption is probably conservative, since surface tension and viscous forces will cause the top half of the pipe to have a thin film. Table 4 shows the calculated film thickness following draining of pipelines.

Table 4. Liquid Film Thickness following pipeline draining

\begin{tabular}{|l|l|l|}
\hline $\begin{array}{l}\text { Strip Effluent Film } \\
\text { Thickness }(\mathrm{mm})\end{array}$ & $\begin{array}{l}\text { Salt Solution Film } \\
\text { Thickness }(\mathrm{mm})\end{array}$ & $\begin{array}{l}\text { Solvent Film } \\
\text { Thickness }(\mathrm{mm})\end{array}$ \\
\hline 0.081 & 0.106 & 0.13 \\
\hline
\end{tabular}




\section{FILM THICKNESS ON MCU VESSELS}

The authors calculated the film thickness following draining on the following MCU process vessels: the salt solution receipt tanks (SSRT), the salt solution feed tank (SSFT), the decontaminated salt solution hold tank (DSSHT), the contactor drain tank (CDT), the strip effluent hold tank (SEHT), the decontaminated salt solution decanter (DSSD), the strip effluent decanter (SED), and the solvent hold tank (SHT).

All of these vessels are horizontal tanks. Table 5 shows the vessel dimensions.

The liquid film volume following draining is calculated as follows. The end caps are modeled as vertical flat disks. The effect of this assumption should be small. In addition, since the vessel is sloped rather than horizontal at the end cap, the film thickness is reduced. The curvature of the end cap also reduces the surface area, which reduces the volume of the film. The MCU tanks have 2:1 elliptical ends. Calculating the volume of these tanks shows a $6 \%$ reduction over tanks with flat ends. ${ }^{15}$ The elliptical heads would reduce the surface area by a similar amount. The length of the vessel is modeled as a horizontal pipe. The film is assumed to cover the entire inner wall of the vessel. The film thickness in the bottom half of the vessel is calculated with equation 9. The film thickness in the top half of the vessel is assumed equal to the film thickness when the wall is vertical $(\cos \theta=1)$. The film thickness is averaged over the surface area, and the average thickness multiplied by the surface area of the vessel (see equation 13).

$$
\mathrm{V}=2 \pi(\mathrm{D} / 2)^{2} \mathrm{~h}_{1}+\pi \mathrm{D} \mathrm{L} \mathrm{h}
$$

In equation $13, \mathrm{D}$ is the tank diameter, $\mathrm{L}$ is the tank length, and $\mathrm{h}_{1}$ is the average film thickness of the end caps and $h_{2}$ is the average film thickness of the pipe.

Table 5. MCU Vessel Dimensions

\begin{tabular}{|l|l|l|l|l|l|l|}
\hline Vessel & Diameter & Length & h-end caps & h-pipe length & Film Volume & $\begin{array}{l}\text { Source Term } \\
\text { Reduction } \\
\text { Factor* }\end{array}$ \\
\hline SSRT & $8.0 \mathrm{ft}$ & $23.75 \mathrm{ft}$ & $0.013 \mathrm{~mm}$ & $0.106 \mathrm{~mm}$ & $1.6 \mathrm{gal}$ & $63 \mathrm{X}$ \\
\hline SSFT & $8.0 \mathrm{ft}$ & $23.75 \mathrm{ft}$ & $0.013 \mathrm{~mm}$ & $0.106 \mathrm{~mm}$ & $1.6 \mathrm{gal}$ & $63 \mathrm{X}$ \\
\hline DSSHT & $8.0 \mathrm{ft}$ & $23.75 \mathrm{ft}$ & $0.013 \mathrm{~mm}$ & $0.106 \mathrm{~mm}$ & $1.6 \mathrm{gal}$ & $63 \mathrm{X}$ \\
\hline CDT & $4.0 \mathrm{ft}$ & $12.0 \mathrm{ft}$ & $0.013 \mathrm{~mm}$ & $0.106 \mathrm{~mm}$ & $0.40 \mathrm{gal}$ & $250 \mathrm{X}$ \\
\hline SEHT & $4.33 \mathrm{ft}$ & $11.75 \mathrm{ft}$ & $0.010 \mathrm{~mm}$ & $0.081 \mathrm{~mm}$ & $0.33 \mathrm{gal}$ & $300 \mathrm{X}$ \\
\hline DSSD & $4.0 \mathrm{ft}$ & $11 \mathrm{ft}$ & $0.013 \mathrm{~mm}$ & $0.106 \mathrm{~mm}$ & $0.37 \mathrm{gal}$ & $270 \mathrm{X}$ \\
\hline SED & $3.0 \mathrm{ft}$ & $7.5 \mathrm{ft}$ & $0.010 \mathrm{~mm}$ & $0.081 \mathrm{~mm}$ & $0.14 \mathrm{gal}$ & $710 \mathrm{X}$ \\
\hline SHT & $3.0 \mathrm{ft}$ & $9.75 \mathrm{ft}$ & $0.024 \mathrm{~mm}$ & $0.13 \mathrm{~mm}$ & 0.30 gal & $330 \mathrm{X}$ \\
\hline
\end{tabular}

* Following 100 gallon flush

Following draining, MCU personnel will flush the SSRTs, SSFT, DSSHT, CDT, and SEHT with $100-200$ gallons of water using spray nozzles (solvent hold tank will not be flushed). Testing of the spray nozzles demonstrated complete coverage of the tanks with the flush water. Since the salt solution and strip solution are miscible with water and the flush water will contact the entire 
interior of the tank, contaminants remaining in the tank following flushing will be reduced according to equation 14

$$
\mathrm{C}_{\mathrm{f}}=\mathrm{C}_{\mathrm{i}}\left[\mathrm{V}_{\text {film }} /\left(\mathrm{V}_{\text {film }}+\mathrm{V}_{\text {flush }}\right)\right]
$$

where $C_{i}$ is the contaminant concentration before flushing, $V_{\text {film }}$ is the film volume, and $V_{\text {flush }}$ is the flush water volume. This calculation assumes complete coverage of the tank wall with the flush water and complete (ideal) mixing.

The following is an example calculation of the cesium remaining in the strip effluent hold tank following draining and flushing. The nominal cesium concentration in the strip effluent is $16.4 \mathrm{Ci} / g a l .{ }^{16}$ The calculated film volume in the strip effluent hold tank following draining is 0.33 gallons. The residual cesium in the strip effluent hold tank following draining is $5.4 \mathrm{Ci}$. Following flushing with 100 gallons of water and assuming complete coverage of the tank walls by the spray nozzle, the cesium concentration in the tank is reduced by $300 \mathrm{X}$ to $0.018 \mathrm{Ci}$. Similar calculations can be performed for other tanks.

The MCU design includes corrugated piping between the contactors. The piping is designed for gravity flow between the contactors. Since the piping is corrugated, it will likely hold addition liquid beyond the amount calculated with equations $1-10$. Following the recent contactor tests at Wright Industries, personnel drained one of the corrugated pipes. Following draining, they positioned the pipe vertically, drained the remaining liquid, and collected $15 \mathrm{~mL}$ of liquid.

We estimated the amount of liquid in the corrugated piping by the following method. We assumed that, following draining, the piping contained a film along a vertical pipe. We assumed the corrugation had a sinusoidal shape and the surface area of the pipe was described by equation 15

$$
\mathrm{A}=\pi^{2} \mathrm{DL} / 2
$$

where $\mathrm{D}$ is the pipe diameter and $\mathrm{L}$ is the pipe length. Table 6 shows the dimensions of corrugated pipes in the MCU process. Since the pipe lengths are $+/-3$ inches, we added 3 inches to the length in calculating the surface area. We multiplied the recommended film thickness from Table 2 by the internal surface area and added $15 \mathrm{~mL}$ for the volume of liquid collected during the tests at Wright Industries. The estimated liquid holdup in these corrugated pipes is 16 $-21 \mathrm{~mL}$.

Table 6. Dimensions of Corrugated Piping

\begin{tabular}{|l|l|l|l|l|l|}
\hline Contactor & Liquid & Length (in) & Diameter (in) & Area $\left(\mathrm{in}^{2}\right)$ & Film Vol (mL) \\
\hline V10 & Salt solution & 43.1 & 2 & 455 & 19.4 \\
\hline V10 & Solvent & 30.7 & 2 & 333 & 20.2 \\
\hline V5 & Strip & 27.4 & 1 & 150 & 16 \\
\hline V5 & Solvent & 26.6 & 1 & 146 & 17.3 \\
\hline
\end{tabular}

Understand that these estimates of film thickness are based on laboratory testing and fluid mechanics theory. The calculations assume drainage occurs by film flow. Much of the data used 
to develop the models came from tests with very "clean" fluids. Impurities in the fluids and contaminants on the vessels walls could increase liquid holdup. The application of film thickness models and source term reduction calculations should be considered along with operational conditions and H-Tank Farm/Liquid Waste operating experience. These calculations exclude the PVV/HVAC duct work and piping, as well as other areas that area outside the scope of this report.

\section{CONCLUSIONS}

The conclusions from this work follow.

- The predicted film thickness of the strip effluent is $0.010 \mathrm{~mm}$ on vertical walls, $0.57 \mathrm{~mm}$ on horizontal walls and $0.081 \mathrm{~mm}$ in horizontal pipes.

- The predicted film thickness of the salt solution is $0.015 \mathrm{~mm}$ on vertical walls, $0.74 \mathrm{~mm}$ on horizontal walls, and $0.106 \mathrm{~mm}$ in horizontal pipes.

- The predicted film thickness of the solvent is $0.022 \mathrm{~mm}$ on vertical walls, $0.91 \mathrm{~mm}$ on horizontal walls, and $0.13 \mathrm{~mm}$ in horizontal pipes.

- The calculated film volume following draining is

○ Salt solution receipt tank - 1.6 gallons

- Salt solution feed tank - 1.6 gallons

○ Decontaminated salt solution hold tank -1.6 gallons

- Contactor drain tank -0.40 gallons

○ Strip effluent hold tank -0.33 gallons

- Decontaminated salt solution decanter -0.37 gallons

- Strip effluent decanter - 0.14 gallons

○ Solvent hold tank -0.30 gallon

○ Corrugated piping between contactors $-16-21 \mathrm{~mL}$

- After the initial vessel draining, flushing the vessels with 100 gallons of water using a spray nozzle that produces complete vessel coverage and draining the flush water reduces the source term by the follow amounts.

○ Salt solution receipt tank $-63 \mathrm{X}$

- Salt solution feed tank - 63X

- Decontaminated salt solution hold tank $-63 \mathrm{X}$

o Contactor drain tank - 250X

○ Strip effluent hold tank - 300X

- Decontaminated salt solution decanter $-270 X$

- Strip effluent decanter $-710 \mathrm{X}$

o Solvent hold tank - 330X

Understand that these estimates of film thickness are based on laboratory testing and fluid mechanics theory. The calculations assume drainage occurs by film flow. Much of the data used to develop the models came from tests with very "clean" fluids. Impurities in the fluids and contaminants on the vessels walls could increase liquid holdup. The application of film thickness models and source term reduction calculations should be considered along with operational conditions and H-Tank Farm/Liquid Waste operating experience. These calculations exclude the PVV/HVAC duct work and piping, as well as other areas that area outside the scope of this report. 


\section{REFERENCES}

1. C. L. Huntoon to G. P. Rudy, memorandum titled 'Preferred Alternative for the Savannah River Salt Processing Project”, June 25, 2001.

2. R. A. Dimenna, H. H. Elder, J. R. Fowler, R. C. Fowler, M. V. Gregory, T. Hang, R. A. Jacobs, P. K. Paul, J. A. Pike, P. L. Rutland, F. G. Smith III, S. G. Subosits, G. A. Taylor, S. G. Campbell, and F. A. Washburn, "Bases, Assumptions, and Results of the Flowsheet Calculations for the Decision Phase Salt Disposition Alternatives", WSRC-RP-99-00006, Rev. 3, May 24, 2001.

3. J. A. Tallmadge and C. Gutfinger, "Entrainment of Liquid Films: Drainage, Withdrawal, and Removal”, Ind. Eng. Chem., vol. 59, No. 11, 19-34, 1967.

4. V. G. Levich, Physicochemical Hydrodynamics, Englewood Cliffs, Prentice-Hall, 1962.

5. P. Groenveld, "Drainage and Withdrawal of Liquid Films", AIChE J., vol. 17, No. 2, pp. 489-490, 1971.

6. R. P. Spiers, C. V. Subbaraman, and W. L. Wilkinson, "Free Coating of a Newtonian Liquid onto a Vertical Surface”, Chem. Eng. Sci., vol. 29, pp. 389-396, 1974.

7. H. Takahama and S. Kato, "Longitudinal Flow Characteristics of Vertically Falling Liquid Films without Concurrent Gas Flows", Int. J. Multiphase Flow, vol. 6, pp. 203$215,1980$.

8. K. Moran, J. Inumaru, and M. Kawaji, "Instantaneous Hydrodynamics of a Laminar Wavy Liquid Film”, Int. J. Multiphase Flow, vol. 28, pp. 731-755, 2002.

9. K. K. Yeong, A. Gavriilidis, R. Zapf, H.-J. Kost, V. Hessel, and A. Boyde, "Characterization of Liquid Film in a Microstructured Falling Film Reactor using Laser Scanning Confocal Microscopy”, Exp. Therm. Fluid Sci., vol 30, 2006, pp. 463-472.

10. J. Mikielewicz and J. R. Moszynski, "Minimum Thickness of a Liquid Film Flowing Vertically Down a Solid Surface”, Int. J. Heat Mass Transfer, vol. 19, 1976, pp. 771-776.

11. G. A. O'Neill and J. W. Westwater, "Dropwise Condensation of Steam on ElectroplatedSilver Surfaces”, Int. J. Heat Mass Transfer, vol. 27, No. 9, 1984, pp. 15391549.

12. L. H. Delmau, J. F. Birdwell, P. V. Bonnesen, L. J. Foote, T. J. Haverlock, L. N. Klatt, D. D. Lee, R. A. Leonard, T. G. Levitskaia, M. P. Maskarinec, B. A. Moyer, F. V. Sloop, and B. A. Tomkins, "Caustic-Side Solvent Extraction: Chemical and Physical Properties of the Optimized Solvent", ORNL/TM-2002-190, October 2002.

13. J. A. Tallmadge, "On the Liquid Film which Occurs in a Draining Vessel”, J. Phys. Chem., vol. 75, No. 4, 1971, pp. 583-585.

14. M. Cachile, R. Chertcoff, A. Calvo, M. Rosen, J. P. Hulin, and A. M. Cazabat, "Residual Film Dynamics in Glass Capillaries”, J. Colloid. Int. Sci., vol. 182, 1996, pp. 483-491.

15. http://www.freecalc.com/vessels.htm.

16. D. D. Walker, "Cesium Concentration in MCU Solvent", WSRC-RP-2005-01970, Rev. 0, January 18, 2006.

\section{ACKNOWLEDGEMENT}

The authors wish to acknowledge Charles Nash for his insight into the occurrence of drop formation during draining of liquid films and the impact of the drops on the drainage of liquids from MCU vessels. Charles provided several of the key references bases on his prior studies. 


\section{APPROVAL}

Author:

Design Check:

Customer:

Management:

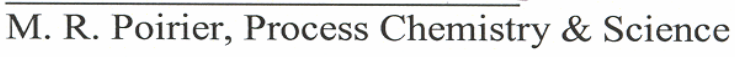

F. F. Fondeur, Process Chemistry \& Science

D. P. Lambert, Process Chemistry \& Science

V. P. LeDonne, MCUDesign Authority

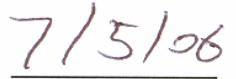

Date

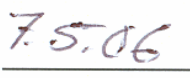

Date

$7-5-06$

Date

$7 / 6 / 06$

Date

J. C. Griffin, Ćhen

$7-6-2006$

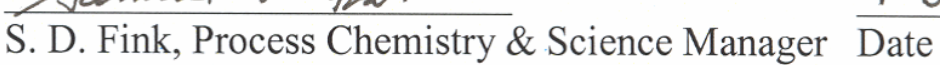

Manager

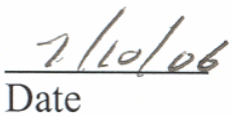

